๑ Entomologica Fennica. 19 September 2003

\title{
Notes on the Palaearctic species of the genus Polylepta Winnertz (Diptera: Mycetophilidae) with a new synonymization
}

\author{
Olavi Kurina
}

\begin{abstract}
Kurina, O. 2003: Notes on the Palaearctic species of the genus Polylepta Winnertz (Diptera: Mycetophilidae) with a new synonymization. — Entomol. Fennica 14: 91-97.
\end{abstract}

Morphological differences between three Palaearctic species of Polylepta Winnertz $-P$. borealis Lundström, $P$. guttiventris (Zetterstedt) and $P$. zonata (Zetterstedt) — are discussed and detailed genital figures for males and females are given. Polylepta meridionalis Bechev, 1990 is shown to be a junior synonym of Polylepta zonata (Zetterstedt, 1852).

Olavi Kurina, Institute of Zoology and Botany of Estonian Agricultural University, Riia st.181,Tartu 51014,Estonia; E-mail: olavi@zbi.ee

Received 7 June 2002, accepted 15 October 2002

\section{Introduction}

The genus Polylepta Winnertz, 1863 belongs to the tribe Schiophilini of the family Mycetophilidae. The genus is easily distinguished from the remaining genera by wing characteristics: the point of furcation of $\mathrm{CuA}$ is before the point of furcation of $\mathrm{M}$, the base of M1 very weak and R5 is curved (Fig. 1). The only revision of Polylepta has been published by Bechev (1990). It includes four species from the Holarctic region: $P$. borealis Lundström, 1912, $P$. guttiventris (Zetterstedt, 1852), P. meridionalis Bechev, 1990 and P. zonata (Zetterstedt, 1852) occur in the Palaearctic subregion, and $P$. borealis and $P$. guttiventris occur also in the Nearctic subregion. Bechev (1990) excluded three species from the genus Polylepta, viz. P. splendida Winnertz, 1863, reported from the Palaearctic subregion by Matile (1988), P. modesta Van Duzee, 1928 and P. nigella Johannsen, 1910, reported from the Nearctic subregion by Laffoon (1965). Moreover, Bechev (1990) treats the Nearctic species Polylepta obediens Johannsen, 1910 as a junior synonym of $P$. guttiventris.
P. dubiosa Brunetti, 1912 has been recorded from the Oriental region (Colless \& Liepa 1973), and the fossil species $P$. filipes Meunier, 1904 has been described by palaeontological records from Baltic amber (Evenhuis 1994). When studying the European material of Polylepta, several problems arose, which brought about a new revision of the Palaearctic species of the genus. The study is based on material collected in Italy, France, Czech Republic, Hungary, Bulgaria, Sweden, Finland and Estonia.

\section{Methods and abbreviations}

In each studied specimen, the genitalia were separated from the abdomen and heated in $15 \% \mathrm{KOH}$ for maceration. The remaining chitinous parts were washed with distilled water and placed into glycerin. The genitalia were preserved as glycerin preparations. Stereo-microscope OLYMPUS SZ4045TR (6.7-240×) and microscope AY-12 (70-300×) were used. The morphological terminology follows Søli (1997).

Abbreviations of the institutions where the material is deposited: IZBE — Institute of Zoology and Botany, Esto- 


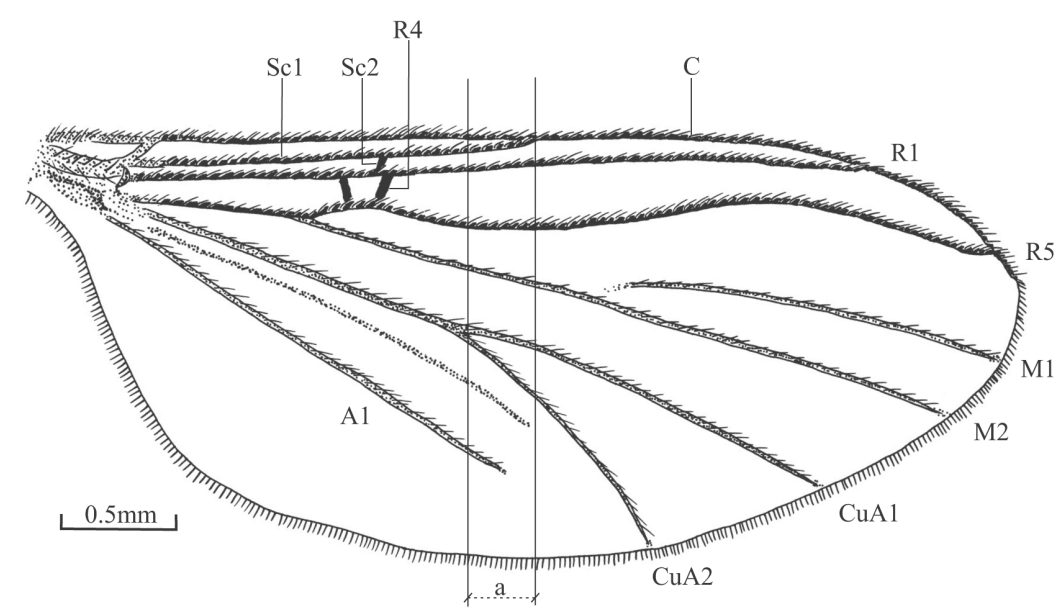

Fig. 1. Wing of Polylepta borealis. A - anal vein; C - costa; CuA1 and CuA2 - anterior branches of cubitus; M1 and M2 - branches of media; R1, R4 and R5 - branches of radius; Sc1 and Sc2 - branches of subcosta; a - measured distance between the point of furcation of CuA and the tip of Sc1.

nian Agricultural University (Tartu); DBPC — Dimitar Bechev personal collection (Plovdiv); MMBC — Moravian Museum (Brno); MNHN — Muséum National d'Histoire Naturelle (Paris); and NHRS — Swedish Museum of Natural History (Stockholm).

\section{The species}

Polylepta borealis Lundström (Figs. 1, 2a-b, 3a-b)

Polylepta borealis Lundström, 1912: 13, figures 13-14.

Polylepta borealis Lundström, 1912: Bechev (1990): 180, figures 3-4; Chandler (1992): 118-119, figures 24 25; Zaitzev (1994): 175, plate 59, figure 4.

Diagnostic characters. Whole wing membrane with macro- and microtrichia. Point of furcation of $\mathrm{CuA}$ before the tip of Sc1. Male: abdomen entirely dark; third section of gonocoxite with two subapical teeth; gonocoxal lobe half as long as third section of gonocoxite and gonostylus with feather-like protuberances on dorsal area. Female: second cercus as long as first; eighth tergite with short bristles with length of about one fourth of length of first cercus.

Material studied. Sweden. 1 \%, Grisslehamn, Upp., 8.VII.1935, Hedgren leg. [NHRS]. Finland. 1 ơ, Sotkamo, Arreniemi, 17.VII.1967, Mihālyi leg.; 1 ơ, Oulanka Biol. Stat., 23.VII.1967, Mihālyi leg.; 1 \&, Lammi Biol. Stat., 7.VII.1967,

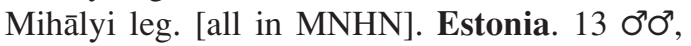

Nigula Nature Reserve, 2.VII.1994, 3.VII.1994, 4.VII.1994, 3.VI.1995 and 4.VI.1995, Kurina leg.; 1 ơ, Aheru, 9.VII.1994, Kurina leg.; 1 ơ, Kiuma, 16.VIII.1995, Kurina leg.; 1 ơ, Jüriküla, 20.VIII.1995, Kurina leg.; 1 O, Lahemaa National Park, Revoja, 24.VI.1988, Kurina leg. [all in IZBE].

Polylepta guttiventris (Zetterstedt) (Figs. 2c-d, 3c-d)

Sciophila guttiventris Zetterstedt, 1852: 4363.

Polylepta undulata Winnertz, 1863: 746; Polylepta undulata var. major Landrock, 1923: 168.

Polylepta guttiventris (Zetterstedt, 1852): Hutson et al. (1980): 48-49, figures 32, 35 and 194; Bechev (1990): 180, figures 1-2; Zaitzev (1994): 175-176, plate 59, figure 2; Søli (1997): figure 29.

Diagnostic characters. Microtrichia on wing membrane present only near veins. Abdomen with lighter to yellow lateral areas on fore margins of second to fifth tergites. Male: third section of gonocoxite apically gradually tapering; gonocoxal lobe completely with small setae and as long as third section of gonocoxite; gonostylus with feather-like protuberances on dorsal area. Female: second cercus as long as first; eighth tergite with strong bristles, about as long as first cercus.

Types. Polylepta undulata var. major Landrock, 1923 — Lectotype (studied): 1 ㅇ, Czech Republic, Bilowitz, 24.V. [no year noted], 
Fig. 2. Male genitalia of Polylepta species. - a. $P$. borealis, ventral view of hypogymnium. - b. $P$. borealis, medial view of gonostylus. - c. P. guttiventris, ventral view of hypogymnium. $-\mathrm{d}$. $P$. guttiventris, medial view of gonostylus. - e. $P$. zonata, ventral view of hypogymnium. - f. $P$. zonata, medial view of gonostylus. Abbreviations: gc I, II and III - gonocoxite sections; gc lb gonocoxal lobe; gst gonostylus; $b$ - featherlike protuberances on dorsal area of gonostylus.

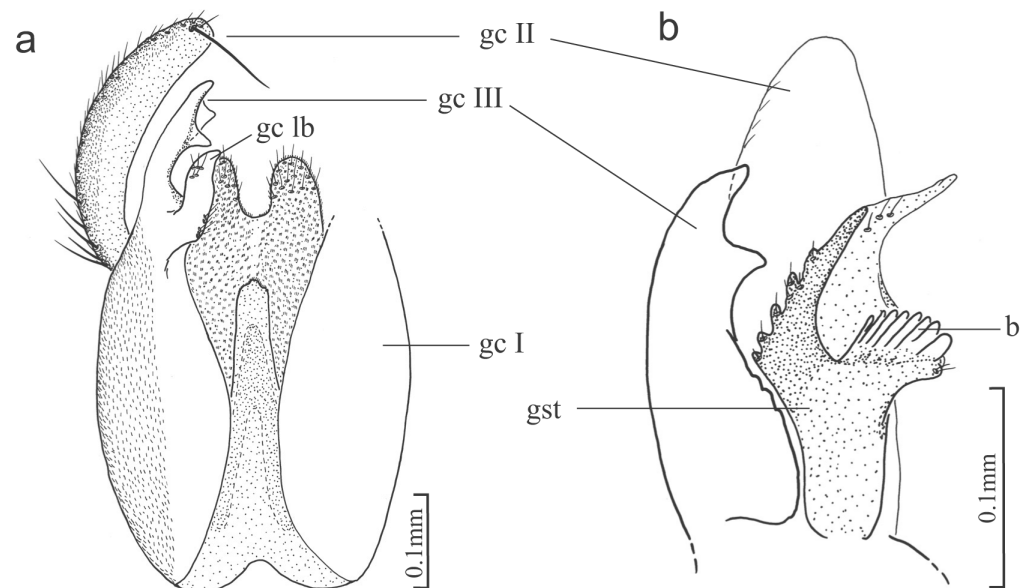

C

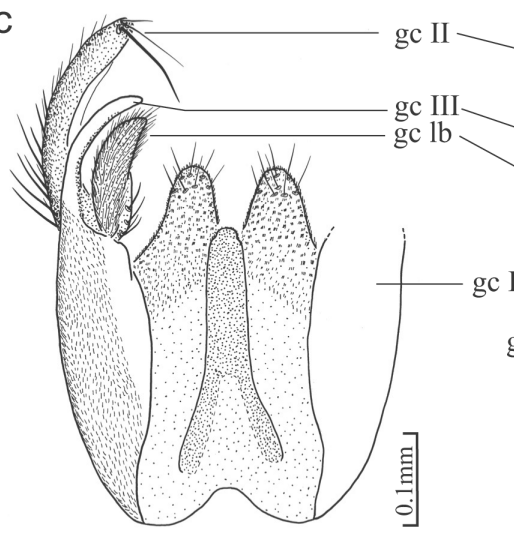

d

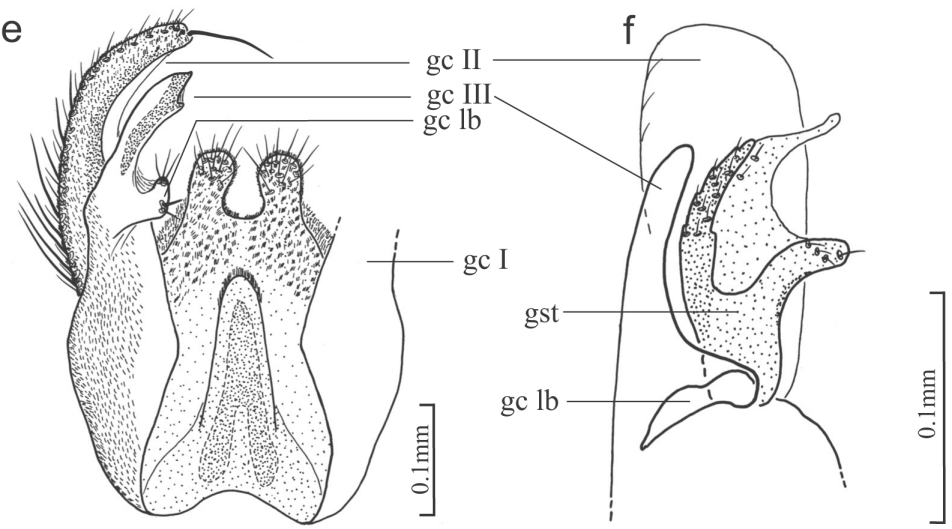

Landrock leg., Invent. No. 1697/Ent. [MMBC]. Paralectotypes (studied): 1 \&, Czech Republic, Bilowitz, 15.V.1911, Landrock leg., Invent. No 1698/Ent.; 1 \&, Czech Republic, Adamstal, 13.V.1911, Landrock leg., Invent. No 1700/Ent. [MMBC].

Material studied. Italy. 1 O', Aosta, Valnontey (alt. 1620-1750 m), 10.VII.1975, D. \& L. Matile leg.; 1 ㅇ, Aosta, Piano di Sylvenoire (alt. 1600-1650 m), 15.VII.1975, D. \& L. Matile leg. [all in MNHN]. France. 1 o', forêt d'Othe (Yonne), 6.VI.1970, L. Matile \& J. J. Menier leg.; $10^{\prime}$, Col de Porte (Isère) (alt. 1300 m), 26.VI.1970, L. Matile leg.; 1 \&, Isola 2000 (alt. 2000 m), 17.VII.1976, J. Clastrier leg. [all in MNHN]. Czech Republic. $10^{\prime \prime}$, Gersdorf, [no date and year noted], Landrock leg. [MMBC]. Swe- 

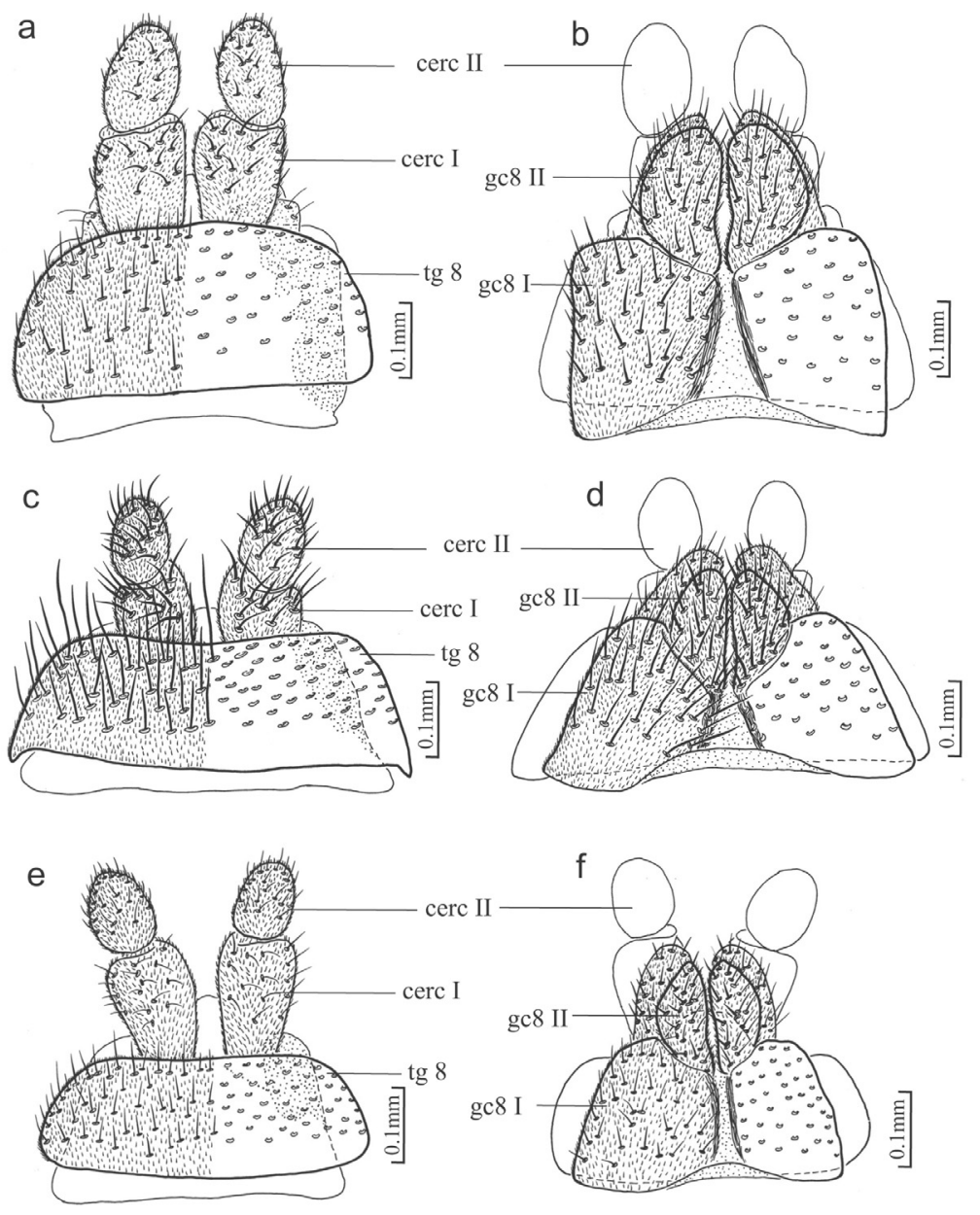

Fig. 3. Female terminalia of Polylepta species. - a. P. borealis, dorsal view. - b. $P$. borealis, ventral view. - c. $P$. guttiventris, dorsal view. d. P. guttiventris, ventral view. - e. P. zonata, dorsal view. - f. P. zonata, ventral view. Abbreviations: cerc - cercus; $\operatorname{tg}$ - tergite; gc8 I and II sections 1 and 2 of gonocoxite 8.

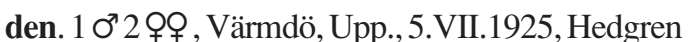
leg.; 1 o’ 1 o, Grisslehamn, Upp., 11.VII. and 12.VII.1935, Hedgren leg. [all in NHRS]. Finland. 1 ơ', N. Esbo, Kolmperä, 4.VII.1967, Mihālyi leg. [MNHN]. Estonia. 1 \%, Oonga, 8.IX.1994, Kurina leg.; 1 0', Tõstamaa, 3.IX.1994, Kurina leg.; 6 0'0", 1 \&, Nigula Nature Reserve, 7.VIII.1990, 2.VII.1994, 3.VI.1995, 9.VII.1995, and 26.VII.1995, Kurina leg.; 3 O'07, Hargla, 7.VII.1994, Kurina leg.; 2 O'ర $^{7}$, Aheru, 8.VII.1994, Kurina leg.; 1 ơ, Apja-Suurjärv, 8.VII.1994, Kurina leg.; 1 o", Taevaskoja, 12.VI.1994, Kurina leg.; 1 o’, Kiuma, 16.VIII.1995, Kurina leg.; 1 Ơ, Jüriküla, 20.VIII.1995, Kurina leg. [all in IZBE].

\section{Polylepta zonata (Zetterstedt) (Figs. 2e-f, 3e-f)}

Sciophila zonata Zetterstedt, 1858: 4136.
Polylepta meridionalis Bechev, 1990: 182, figures 56, syn. nov.; Chandler (1998): 123.

Diagnostic characters. Whole wing membrane with macro- and microtrichia. Abdomen with pale to yellow lateral areas on anterior margins of second to fifth tergites. Male: third section of gonocoxite apically sharp, with a subapical low tooth; gonocoxal lobe about one third as long as third section of gonocoxite; gonostylus without feather-like protuberances on dorsal area but with a few normal setae. Female: second cercus about 1.5 times as long as first; the eighth tergite with short bristles, about one fifth to one fourth as long as first cercus.

On the basis of the material studied and on analysis of literature, $P$. meridionalis is identified as a junior synonym of $P$. zonata (see Discussion for more details).

Types. Polylepta meridionalis Bechev, 1990 Paratype (studied): $10^{7}$, Bulgaria, Slavjanka Mt., v. Goleshovo, 07.VI.1988, D. Bechev leg. [DBPC]. 
Material studied. France. $10^{7} 1$ ㅇ, Corsica, forest of Zonza (alt.750 m ), 06. VI. 1972, L. Matile leg.; 1 o', Corsica, Bord de Ruisseau, Maouis de l'Ospèdale, 7.VI.1972, L. Matile leg. [all in MNHN]. Czech Republic. 2 o' $0^{\prime \prime}$, Bilowitz, 4.VI. [no year noted], Landrock leg.; 1 O’, Adamstal, 27.V.1911, Landrock leg. [all in MMBC]. Hungary. $10^{\prime \prime}$, Köszeg, Velemi erdö, 11.VII.1960,Zsirko leg.; 1 ㅇ, Köszeg, Szabónegy, 6.VII.1960, Mihālyi leg. [all in
MNHN]. Sweden. $10^{7}$, Grisslehamn, Upp, 12.VII.1935, Hedgren leg; 1 ㅇ, Värmdö, Upp., 21.VI.1925, Hedgren leg. [all in NHRS].

\section{Discussion}

Three groups of specimens could clearly be distinguished in the European material. The speci-

Table 1. Morphological characteristics of three Polylepta Winnertz species.

\begin{tabular}{lll}
\hline$P$. borealis & $P$. guttiventris & $P$. zonata \\
\hline WING & & \\
whole wing membrane with & microtrichia present only near & whole wing membrane with macro- \\
macro- and microtrichia; the & veins; location of furcation point of & and microtrichia; location of furcation \\
point of furcation of CuA always & CuA variable: before or below the & point of CuA variable: after or below \\
before the tip of Sc1, the distance & ip of Sc1 (usually below in males & the tip of Sc1 (in very few cases \\
between them $0.16-0.26 \mathrm{~mm}$ & and before in females) & before)
\end{tabular}

(Fig. 1)

\section{ABDOMEN}

males: entirely dark; females: sometimes undistinguishable lighter lateral areas present on tergites II-V

\section{MALE GENITALIA}

III section of gonocoxite (gc III) apically toothed (Fig. 2a-b)

\section{Gonocoxal lobe (gc lb)}

about half as long as gc III, with short bristles: $4-5$ preapically and 5-6 basally (Fig. 2a)

Gonostylus (gst)

with feather-like protuberances on dorsal area (Fig. 2b, d) apically uniformly narrowing

(Fig. 2c-d)

about as long as gc III completely with small setae and with 4-5 bristles basally (Fig. 2c) apically truncated (Fig. 2e-f)

less than one third of length of gc III, with short bristles: 3 apically and 2 basally (Fig. 2e)

dorsal area without such kind of protuberances (Fig. 2f)

\section{FEMALE TERMINALIA}

Cerci

cercus II about as long as cercus I (Fig. 3a, c)

VIII tergite with short bristles (Fig. 3a)

with strong bristles of the length of with short bristles (Fig. 3e) cercus I (Fig. 3c)

VIII gonocoxite section I nearly quadrate, section II sinks into section I by one third of its length (Fig. 3b) section I apically slightly tapering, section II sinks into the section I by one third of its length (Fig. 3f) section I apically particularly tapering, section II sinks into the section I by half of its length (Fig. 3d) 
mens of the first group had the genital structure as given in Figs. $2 \mathrm{a}-\mathrm{b}$ and $3 \mathrm{a}-\mathrm{b}$, the whole wing membrane covered with microtrichia, and the point of furcation in $\mathrm{CuA}$ always before the tip of Sc1. These are characteristics for $P$. borealis. The second group had the genital structure as given in Figs. $2 c-d$ and $3 c-d$. Microthichia on wing membrane were present only near veins, and the point of furcation in $\mathrm{CuA}$, in relation to the tip of Sc1, was variable - characteristics of $P$. guttiventris. The third group was well distinguished by genital structure (Figs. 2e-f, 3e-f) and agreed with the description of $P$. meridionalis. However, based on wing characteristics, the group was variable (Table 1). Most of the material examined agreed with the description of $P$. zonata (Zetterstedt 1852, Bechev 1990). P. zonata has previously been known only from the Swedish type specimen with missing abdomen (Edwards 1925, Bechev 1990). Bechev (1990) suggested that $P$. zonata and $P$. meridionalis could be distinguished on the basis of wing characteristics, in particular of the level of the furcation point in $\mathrm{CuA}$. However, as this detail varies considerably, these cannot be used to distinguish between these two species. Consequently, $P$. meridionalis should be considered as a junior synonym of $P$. zonata - a view also supported by D. Bechev (pers. comm.).

The details of gonostylus, which are specific and important for the identification of the species, have not been previously illustrated. Moreover, the differences on the structure of terminalia among females have not previously been discussed, although the female terminalia of $P$. guttiventris have been illustrated (figure $40 \mathrm{~B}-\mathrm{C}$ in Søli [1997]). Differences between the species, especially in male and female genitalia with reference to the respective figures, are shown in Table 1.

$P$. guttiventris is a Holarctic species, widely distributed in Europe (Matile 1988), while $P$. borealis is a Holarctic boreo-alpine species (Chandler 1992). P. zonata is probably rare but widely distributed in Europe, so far recorded in France (Corsica), Czech Republic, Hungary, Bulgaria and Sweden. Reports concerning the biology exist only for $P$. borealis that is found from the folds of Gyromitra esculenta (Yakovlev 1994).
Acknowledgements. I am much obliged to Dr. T. Pape (Swedish Museum of Natural History, Stockholm, Sweden), Dr. M. Baylac (Muséum National d'Histoire Naturelle, Paris, France) and Dr. P. Lauterer (Moravian Museum in Brno, Czech Reublic) for an opportunity to work with the collections. My very special thanks are due to Dr. D. Bechev (Plovdiv, Bulgaria) for his kind advice and for the loan of material. The study was financially supported by grant 4990 of Estonian Science Foundation. I am greatly indebted to Mrs. M. Roos for reading the manuscript.

\section{References}

Bechev, D. 1990: Review of the Holarctic Species of Genus Polylepta Winnertz (Insecta, Diptera: Mycetophilidae). - Entomol. Abh. Mus. Tierkd. Dresden 53: 179-184.

Chandler, P. 1992: New records and nine additions to the British list of fungus gnats of the smaller families and sub-families (Diptera: Mycetophiloidea). — Br. J. Ent. Nat. Hist. 5: 107-126.

Chandler, P. 1998: 20. Mycetophilidae. — In: Merz, B., Bächli, G., Haenni, J.-P. \& Gonseth, Y. (eds.), Fauna Helvetica 1. Diptera - Checklist: 113-125. CSCF und Schweizerische Entomologische Gesellschaft.

Colless, D. H. \& Liepa, Z. 1973: Superfamily Mycetophiloidea. - In: Delfinado, M. D. \& Hardy, D. E. (eds.), A catalog of the Diptera of the Oriental region: 444463. The University Press of Hawaii, Honolulu.

Edwards, F. W. 1925: Notes on the types of Mycetophilidae (Diptera) described by Staeger and Zetterstedt. Entomologisk Tidskrift 45: 160-168.

Evenhuis, N. L. 1994: Catalogue of the fossil flies of the world (Insecta: Diptera). — Backhuys Publishers, Leiden. 600 pp.

Hutson, A. M., Acland, D. M. \& Kidd, L. N. 1980: Mycetophilidae (Bolitophilinae, Ditomyiinae, Diadocidiinae, Keroplatinae, Sciophilinae and Manotinae). - Handbooks for the identification of British Insects 9: 1-112.

Laffoon, J. L. 1965: Superfamily Mycetophiloidea. — In: Stone, A., Sabrosky, C. W., Wirth, W. W., Foote, R. H. \& Coulson, J. R. (eds.), A Catalog of the Diptera of America North of Mexico: 197-229. United States Department of Agriculture, Washington.

Landrock, K. 1923: Die Pilzmücken Mährens. I. Nachtrag. Wien. Ent. Ztg. 40: 163-171.

Lundström, C. 1912: Beiträge zur Kenntnis der Dipteren Finlands VIII. Supplement 2. Mycetophilidae, Tipulidae, Cylindrotomidae und Limnobiidae. - Acta Soc. Fauna Flora Fennica 36: 1-70.

Matile, L. 1988: Tribe Sciophilini. — In: Soós, A. \& Papp, L. (eds.), Catalogue of Palaearctic Diptera. Vol. 3. Ceratopogonidae-Myetophilidae: 231-241. Akademiai Kiado, Bupest. 
Søli, G. E. E. 1997: On the morphology and phylogeny of Mycetophilidae, with a revision of Coelosia Winnertz (Diptera, Sciaroidea). — Ent. scand. Suppl. 50. 137pp. Yakovlev, E. E. 1994: Palaearctic Diptera associated with fungi and myxomycetes. — Petrozavodsk. 127 pp. [In Russian with English summary].
Zaitzev, A. I. 1994: Fungus gnats of the fauna of Russia and adjacent regions. Part. 1. (Ditomyiidae, Bolitophilidae, Diadocidiidae, Keroplatidae, Mycetophilidae). — Nauka, Moscow. 288 pp. [In Russian].

Zetterstedt, J. W. 1852: Diptera Scandinaviae, disposita et descripta. 11. - Lundae. 